\title{
GROWTH, GAS EXCHANGES AND PRODUCTION OF BEET CV. KATRINA UNDER ORGANO-MINERAL FERTILIZATION
}

\author{
CRESCIMENTO, TROCAS GASOSAS E PRODUÇÃO DA BETERRABA CV. KATRINA \\ SOB ADUBAÇÃO ORGANOMINERAL
}

\author{
Hélio Tavares de OLIVEIRA NETO ${ }^{1}$; Ancélio Ricardo de Oliveira GONDIM²; \\ Francisco Vanies da Silva SÁ ${ }^{3}$; Lauter Silva SOUTO ${ }^{2}$; Marcos Eric Barbosa BRITO²; \\ Marcio Santos da SILVA ${ }^{1}$; Renato Pereira de LIRA ${ }^{4}$ \\ 1. Bacharel em Agronomia, Universidade Federal de Campina Grande - UFCG, Campina Grande, PB, Brasil. 2. Professor, Doutor - \\ UFCG, Pombal, PB, Brasil; 3. Doutorando em Engenharia Agrícola - UFCG, Campina Grande, PB, Brasil. \\ vanies_agronomia@hotmail.com; 4 Mestrando em Horticultura Tropical - UFCG, Campina Grande, PB, Brasil.
}

\begin{abstract}
The beet culture has great economic and food importance in the world, especially with respect to energy generation. In Brazil the culture is still little studied, lacking studies in all stages of production of culture, mainly in the management of fertilization. This study aimed to evaluate the effect of organo-mineral fertilization on growth, gas exchanges and production of beet, cv. Katrina. The experiment was conducted under field conditions in the municipality of Pombal-PB, Brazil, from September to December 2015, in a randomized block design. The treatments were arranged in a 4 x 2 factorial scheme and corresponded to four periods of fermentation of the biofertilizer (10, 20, 30 and 40 days) applied in soils with and without mineral fertilization, with four replicates and 18 plants evaluated per plot. Plants were conducted for 70 days after transplanting, in 15-cm-high, 1-m-wide beds. During this period, plant growth, gas exchanges and production components were evaluated. The application of mineral biofertilizer fermented for 20 to 30 days, associated with mineral fertilization with $36 \mathrm{~g} \mathrm{~m}^{-2}$ of $\mathrm{P}_{2} \mathrm{O}_{5}, 18.0 \mathrm{~g} \mathrm{~m}^{-2}$ of $\mathrm{K}_{2} \mathrm{O}$ and $14 \mathrm{~g} \mathrm{~m}^{-2}$ of $\mathrm{N}$ at planting, promoted better performance of growth, gas exchanges and production of beet plants. In the soil without mineral fertilization, it is recommended to use the longest biofertilizer fermentation periods, 30 to 40 days, for beet cultivation.
\end{abstract}

KEYWORDS: Mineral fertilization. Beta vulgaris L. Fermentation. Liquid fertilizer.

\section{INTRODUCTION}

Beet (Beta vulgaris L.) is a dicotyledonous plant, belonging to the Chenopodiaceae family, with tuberous, globular-shaped root that develops almost on soil surface, with markedly sweet taste and purple color, which can be used as vegetable, forage or raw material for sugar production, and these latter uses prevail in Europe (SHRESTHA et al., 2010). Although it is not among the vegetable crops of highest economic value in Brazil, the crop is important in a large number of small properties of the green belts, which have a great diversity of cultivation of vegetables, but with low yield (CORRÊA et al., 2014).

Considering that crops with tuberous roots, such as beet, respond very well to the application of nutrients when it is correctly performed (SILVA et al., 2012), the use of organo-mineral fertilization in their cultivation is a strong ally in the search for an increase in production, for adequately supplying their nutritional requirements, improving soil physical, chemical and biological characteristics, besides reducing production costs, due to the lower use of mineral fertilizers (ALVES et al., 2009; SANTOS et al., 2012; GOMES et al., 2015), making the crop more profitable from the economic point of view.

Among the inputs with potential use in this production system, liquid biofertilizers in the form of simple or enriched microbial-fermented products stand out, due to their quantities of the elements, diversity of mineral nutrients and availability of nutrients through biological activity, which positively help plant growth (ALVES et al., 2009).

In the literature, there are many studies on the effects of biofertilizers on the growth, gas exchanges and production of various vegetables, such as lettuce (ARAÚJO et al., 2007), bell pepper (ALVES et al., 2009), tomato (GOMES JÚNIOR et al., 2011), pumpkin (SANTOS et al., 2012), melon (VIANA et al., 2013; SANTOS et al., 2014) and gherkin (GOMES et al., 2015).

Furthermore, for the production of biofertilizers, one must use organic products with or without the addition of minerals that undergo a process of fermentation, which interferes with the availability of nutrients. Thus, the ideal time for the use of biofertilizer may vary according to the nutritional demand of the species to be cultivated and, for the beet crop, it can be defined by studying its growth, gas exchanges and root production with 
the use of biofertilizers produced with different fermentation periods.

Hence, this study aimed to evaluate the effects of organo-mineral fertilization on the growth, gas exchanges and production of the beet crop, cv. Katrina.

\section{MATERIAL AND METHODS}

The study was conducted under field conditions from September to December 2015, at the Center of Sciences and Agri-food Technology of the Federal University of Campina Grande, Campus of Pombal-PB, Brazil (6 $46^{\prime} 12^{\prime \prime}$ S; 37 $48^{\prime} 7^{\prime}$ ' W; $184 \mathrm{~m})$. According to Köppen's classification, the local climate is BSw'h', characterized as dry hot semi-arid, with mean annual rainfall of $700 \mathrm{~mm}$, high temperatures, leading to strong evaporation, mean annual temperature of $30.5^{\circ} \mathrm{C}$, with only two well defined climatic seasons along the year, one rainy and the other dry.

The soil of the area was classified as Entisol, with loamy sand texture (coarse sand $=801$; silt $=143$ and clay $=56 \mathrm{~g} \mathrm{~kg}^{-1}$ ), and the mean values of its chemical analysis, before experiment installation, were: $\mathrm{pH}$ in $\mathrm{CaCl}_{2}=7.4 ; \mathrm{P}=163 \mathrm{mg} \mathrm{dm}^{-}$ ${ }^{3} ; \mathrm{K}^{+}=0.40 ; \mathrm{Na}^{+}=0.22 ; \mathrm{Ca}^{+2}=6.3 ; \mathrm{Mg}^{+2}=5.6 ; \mathrm{Al}^{+3}$ $=0.0 ; \mathrm{H}^{+}+\mathrm{Al}^{+3}=0.0 ; \mathrm{SB}=14.2$ and $\mathrm{CEC}=14.2$ $\mathrm{cmol}_{\mathrm{c}} \mathrm{dm}^{-3} ; \mathrm{OM}=3.0 \mathrm{~g} \mathrm{~kg}^{-1}$.

The experimental design was randomized blocks, with treatments arranged in a $4 \times 2$ factorial scheme, consisting of four periods of fermentation of the biofertilizer (10, 20, 30 and 40 days) applied in soils with and without mineral fertilization, with four replicates and 18 plants evaluated per plot.

The experiment used the beet cultivar Katrina, which belongs to the Wonder group. Sowing was performed directly onto the beds (seedstarting trays) and, after total emergence, plants were transplanted to the definitive beds. The beds were dimensioned with height of $0.15 \mathrm{~m}$ and width and length of $1.0 \mathrm{~m}$. Each bed contained four plant rows, at the spacing of $25 \mathrm{~cm}$ between rows and 10 $\mathrm{cm}$ between plants in the row, totaling 40 plants per bed. The experimental plot consisted of a $1-\mathrm{m}^{2}$ bed and the evaluation area was considered as the area comprehended by the two central rows of the bed, disregarding the plants on each side, totaling 18 plants evaluated in each plot.

The beds initially received organic fertilization with bovine manure, which was previously aged for 30 days, at the proportion of 2 $\mathrm{kg} \mathrm{m}^{-2}$; its chemical characteristics are shown in Table 1. The treatments with fertilization received the application of $36 \mathrm{~g} \mathrm{~m}^{-2}$ of $\mathrm{P}_{2} \mathrm{O}_{5}$ and $18.0 \mathrm{~g} \mathrm{~m}^{-2}$ of $\mathrm{K}_{2} \mathrm{O}$ five days before transplanting the seedlings. Top-dressing fertilization used $14 \mathrm{~g} \mathrm{~m}^{-2}$ of $\mathrm{N}$, which was split into three equal doses, at 15,30 and 45 days after emergence, according to Raij et al. (1997).

Table 1. Chemical characteristics of the bovine manure used in the experiment.

\begin{tabular}{|c|c|c|c|c|c|c|c|c|c|c|c|}
\hline EC & $\mathrm{pH}$ & $\mathrm{P}$ & $\mathrm{K}^{+}$ & $\mathrm{Ca}^{+2}$ & $\mathrm{Mg}^{+2}$ & $\mathrm{Na}^{+}$ & $\mathrm{Al}^{3+}$ & $\mathrm{H}^{+}+\mathrm{Al}^{3+}$ & SB & CEC & MO \\
\hline $\mathrm{dS} \mathrm{m}^{-1}$ & $\mathrm{CaCl}_{2}$ & $\mathrm{mg} \mathrm{dm}^{-3}$ & 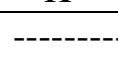 & & & $--\mathrm{cmc}$ & $\mathrm{dm}^{-3}-$ & & & & $\mathrm{g} \mathrm{kg}^{-3}$ \\
\hline 4,26 & 7,75 & 264,0 & 14,64 & 5,70 & 11,90 & 6,18 & 0,00 & 0,00 & 38,42 & 38,42 & 385 \\
\hline
\end{tabular}

$\mathrm{P}, \mathrm{K}$, Na: Mehlich-1 extractor; $\mathrm{Al}, \mathrm{Ca}, \mathrm{Mg}: 1.0 \mathrm{~mol} \mathrm{~L}^{-1} \mathrm{KCl}$ extractor; $\mathrm{SB}=\mathrm{Ca}^{+2}+\mathrm{Mg}^{+2}+\mathrm{K}^{+}+\mathrm{Na}^{+} ; \mathrm{H}^{+}+\mathrm{Al}^{+3}$ : Extracted by $0.5 \mathrm{~mol} \mathrm{~L}^{-1}$ calcium acetate, at $\mathrm{pH} 7.0 ; \mathrm{CEC}=\mathrm{SB}+\mathrm{H}^{+}+\mathrm{Al}^{+3}$; $\mathrm{OM}$ : Walkley-Black Wet Digestion.

The biofertilizer was manufactured based on the anaerobic fermentation, performed using 200-L barrels with a hose connected to a transparent plastic bottle with water for the removal of the methane gas produced inside the container, through the fermentation of anaerobic bacteria (Table 2). The biofertilizer was prepared using the following materials: chopped leaves of leguminous species (4 $\mathrm{kg})$, ground grains of corn, bean and rice $(1 \mathrm{~kg}$ each), Bovine milk (2 L), Sugarcane juice (2 L), Ashes $(1 \mathrm{~kg})$, Fresh bovine manure $(5 \mathrm{~kg})$ and Borax $(1 \mathrm{~g})$. These materials were diluted in water until completing the volume of $200 \mathrm{~L}$ of solution, which was fermented for 10, 20, 30 and 40 days, according to each treatment.
The biofertilizers were applied three times, at 15, 30 and 45 days after emergence, according to the treatments. The application was performed using $1 \mathrm{~L} \mathrm{~m}^{-1}$ of biofertilizer with a concentration of $5 \%$, according to Alves et al. (2004).

Irrigations were performed using a microsprinkler system, twice a day (morning and afternoon), providing a water depth of approximately $8 \mathrm{~mm} \mathrm{day}{ }^{-1}$, corresponding to the mean daily evapotranspiration of the region. The other cultivation practices, weed control, soil chiseling and pest control, were performed always when necessary. 
Table 2. Concentration of micronutrients in the biofertilizers as a function of the fermentation periods.

\begin{tabular}{cccccc}
\hline Fermentation period (days) & $\mathrm{N}$ & $\mathrm{P}$ & \multicolumn{1}{c}{$\mathrm{K}^{+}$} & $\mathrm{Ca}^{+2}$ & $\mathrm{Mg}^{+2}$ \\
\cline { 2 - 6 } & $----\mathrm{mg} \mathrm{L}^{-1}$ & 3,99 & 2095,68 & 256.24 & 374,12 \\
10 & 68,20 & 4,35 & 2552,00 & 724,32 & 479,66 \\
20 & 85,31 & 9,34 & 2455,57 & 1002,08 & 544,82 \\
40 & 85,61 & 10,12 & 2424,73 & 718,50 & 500,72 \\
\hline
\end{tabular}

The gas exchanges of the plants were determined using the LCProt portable photosynthesis meter (ADC BioScientific Ltda), operating with irradiation of $1200 \mu \mathrm{mol}$ photons $\mathrm{m}^{-2}$ $\mathrm{s}^{-1}$ and $\mathrm{CO}_{2}$ from the environment at height of $3 \mathrm{~m}$ from soil surface, obtaining the following variable:

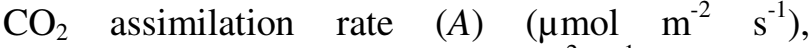
transpiration $(E)$ (mol of $\mathrm{H}_{2} \mathrm{O} \mathrm{m} \mathrm{m}^{-2} \mathrm{~s}^{-1}$ ), stomatal conductance $(g s)$ (mol of $\mathrm{H}_{2} \mathrm{O} \mathrm{m}^{-2} \mathrm{~s}^{-1}$ ) intercellular $\mathrm{CO}_{2}$ concentration $(\mathrm{Ci})\left(\mu \mathrm{mol} \mathrm{m} \mathrm{m}^{-2} \mathrm{~s}^{-1}\right)$, based on readings performed on the third leaf counted from the apex, 60 days after transplanting (DAT) the beet plants.

Beet plants were harvested at 70 DAT and then evaluated for: i) plant height $(\mathrm{PH})$, measured with a ruler graduated in centimeters $(\mathrm{cm})$ from the base until the last photosynthetically active leaf; ii) number of leaves per plant (NL), through the count of mature leaves; iii) tuberous root diameter (TRD), measured with a digital caliper as the longest longitudinal distance of the beetroot and expressed in centimeters $(\mathrm{cm})$; iv) tuberous root fresh and dry matter (TRFM and TRDM) and leaf fresh and dry matter (LFM and LDM), obtained through the collection of the material, washing (running water, 3 $\mathrm{ml} \mathrm{L}^{-1}$ detergent solution, running water, $0.1 \mathrm{~mol} \mathrm{~L}^{-1}$ $\mathrm{HCl}$ solution and distilled water, respectively), partition, drying in a forced-air oven at $65^{\circ} \mathrm{C}$ for 72 $\mathrm{h}$ and weighing on an analytical scale, with values expressed in grams per plant $\left(\mathrm{g}_{\text {plant }}{ }^{-1}\right)$.
The obtained data were subjected to analysis of variance by $F$ test. When the evaluated characteristics were significant, regression analysis was applied for the quantitative factor (fermentation), fitting the models based on the significance of the regression coefficients, using the Student's t-test, on determination coefficients and on the biological phenomenon. For the qualitative factor (presence and absence of mineral fertilization), the $\mathrm{F}$ test becomes conclusive. All tests were performed at 0.05 probability level using the statistical program SISVAR-ESAL version 5.1 (FERREIRA, 2011).

\section{RESULTS AND DISCUSSION}

There was significant difference $(\mathrm{p}<0.05)$ between the treatments with and without the addition of mineral fertilization on the variables plant height $(\mathrm{PH})$, number of leaves (NL), transpiration $(E)$ and stomatal conductance $(g s)$. The highest means occurred in plants cultivated in soil with NPK mineral fertilization, with mean values on the order of $27.08 \mathrm{~cm}$ in $\mathrm{PH}, 6.84$ leaves, $4.39 \mathrm{mmol}$ $\mathrm{m}^{-2} \mathrm{~s}^{-1}$ of $E$ and $0.22 \mathrm{mmol} \mathrm{m}^{-2} \mathrm{~s}^{-1}$ of $g s$, which were respectively $20 \%, 23 \%, 15 \%$ and $18 \%$ higher than those observed in plants cultivated in soil without mineral fertilization (Table 3)..

Table 3. Height (PH) number of leaves (NL), transpiration (E) and stomatal conductance (Gs) of beet plants cultivated with and without NPK fertilization.

\begin{tabular}{ccccc}
\hline \multirow{2}{*}{ NPK } & PH & NL & $E$ & $G s$ \\
\cline { 2 - 5 } & $\mathrm{cm}$ & ---- & \multicolumn{2}{c}{$--\left(\mathrm{mmol} \mathrm{m}^{-2} \mathrm{~s}^{-1}\right)--$} \\
\hline Without & $21,59 \mathrm{~b}$ & $6,84 \mathrm{~b}$ & $3,75 \mathrm{~b}$ & $0,18 \mathrm{~b}$ \\
With & $27,08 \mathrm{a}$ & $8,88 \mathrm{a}$ & $4,39 \mathrm{a}$ & $0,22 \mathrm{a}$ \\
DMS & 2,98 & 0,91 & 0,56 & 0,034 \\
\hline
\end{tabular}

Means followed by different letters differ by the $\mathrm{F}$ test at 0.05 probability level.

Thus, it can be claimed that the mineral fertilization released nutrients satisfactorily, conditioning plants with increased vigor and, consequently, higher growth and gas exchanges. This is confirmed by Catuchi et al. (2012), who studied the physiological responses of soybean plants under potassium fertilization and water regimes, and observed an increment in stomatal conductance with the increase in the potassium dose. In addition, the improvement in the availability of nutrients contributes to the gas exchanges and growth of the plants (SEDIYAMA et al., 2014; SANTOS et al., 2014; SÁ et al., 2016). 
On the other hand, Araújo et al. (2011) worked with organic and mineral fertilization in the lettuce crop and observed lower means for the evaluated variables when plants received mineral fertilization doses, in comparison to plants treated with organic fertilization, which increased the availability of nutrients in the soil

There was significant influence $(p<0.05)$ of the biofertilizer fermentation periods on the gas exchanges of beet plants. The highest values of $\mathrm{CO}_{2}$

(A)

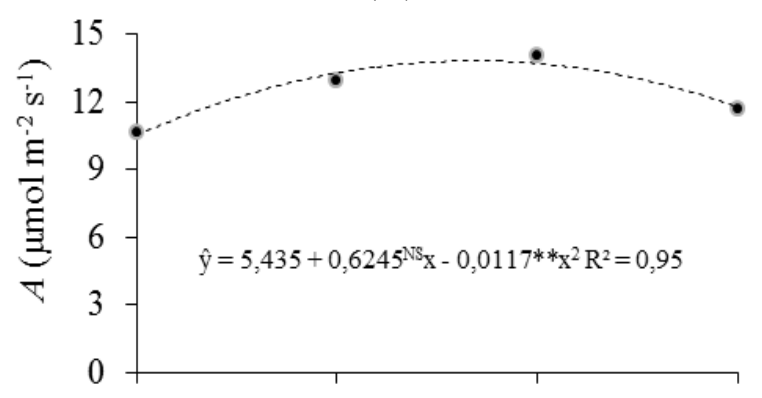

(C)
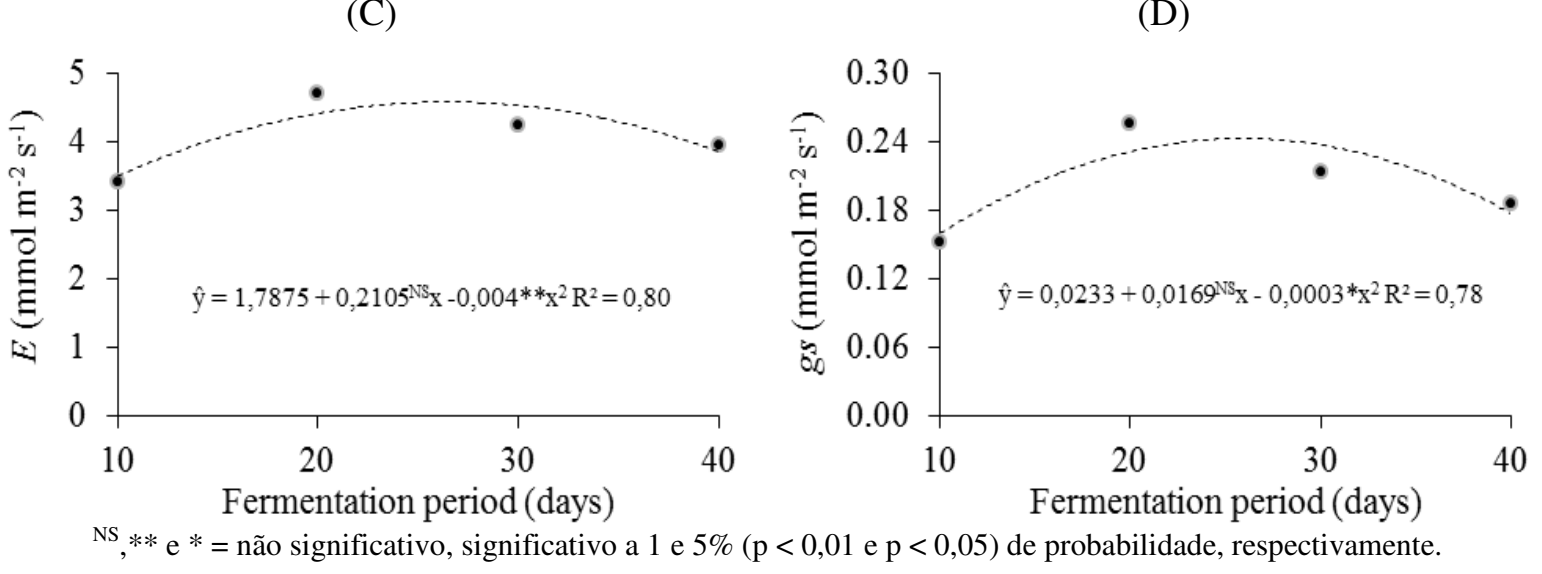

$\left(13.8 \mu \mathrm{mol} \mathrm{m} \mathrm{m}^{-2} \mathrm{~s}^{-1}\right)$, intercellular $\mathrm{CO}_{2}$ concentration $\left(232.19 \mu \mathrm{mol} \mathrm{m}^{-2} \mathrm{~s}^{-1}\right)$, transpiration $\left(4.55 \mathrm{mmol} \mathrm{m}^{-2}\right.$ $\left.\mathrm{s}^{-1}\right)$ and stomatal conductance $\left(0.24 \mathrm{mmol} \mathrm{m} \mathrm{m}^{-2} \mathrm{~s}^{-1}\right)$, were obtained when the biofertilizer was fermented for 27, 24, 26 and 28 days, respectively (Figure 1A, $\mathrm{B}, \mathrm{C}$ and $\mathrm{D})$. The highest values of gas exchanges occurred in plants fertilized with biofertilizer fermented for 20 to 30 days, corresponding to the periods with the highest concentrations of nutrients in the input (Table 2).

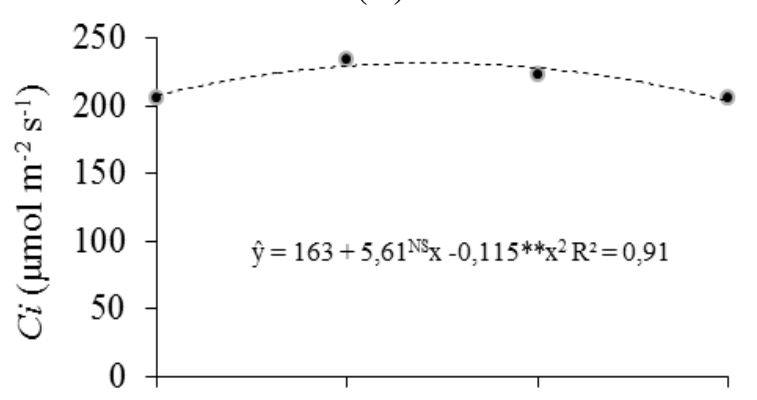

(D)

Figure 1. $\mathrm{CO}_{2}$ assimilation rate $(A)$, intercellular $\mathrm{CO}_{2}$ concentration $(C i)$, transpiration $(E)$ and stomatal conductance $(g s)$ of beet plants under fertilization with common and NPK-enriched biofertilizer in different fermentation periods.

The results indicate that the fertilization with biofertilizer promotes increase in photosynthetic activity and growth of beet plants, which can be attributed to the improvement in soil physical and chemical properties (ALVES et al., 2009; SANTOS et al., 2012; GOMES et al., 2015). Similar results were observed by Silva et al. (2010) in lettuce plants under organic fertilization with biofertilizer; these authors observed that the application of the input also stimulated the physiological activity of lettuce plants.

Additionally, the fertilization with biofertilizer fermented for periods shorter than 20 days and longer than 30 days promoted lower activities in the gas exchanges (Figure 1), a fact attributed to the low availability of nutrients in the 
decomposition of the materials with higher $\mathrm{C} / \mathrm{N}$ ratio.

There was significant influence $(\mathrm{p}<0.05)$ of the interaction between the fermentation periods of the biofertilizer applied to the soil with and without

(A)

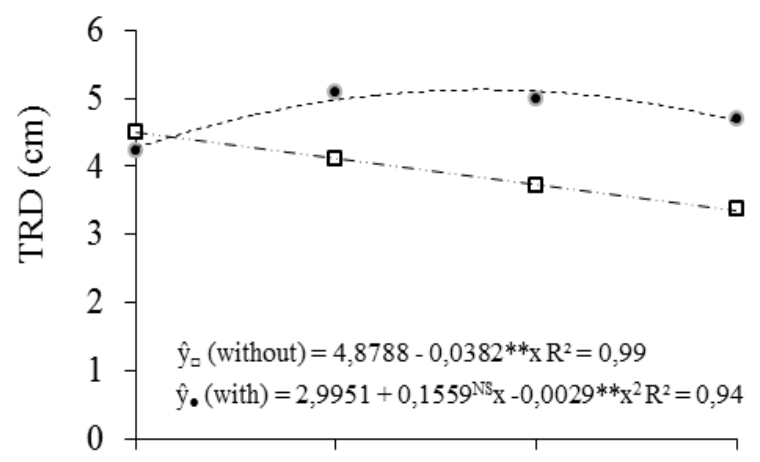

(C)

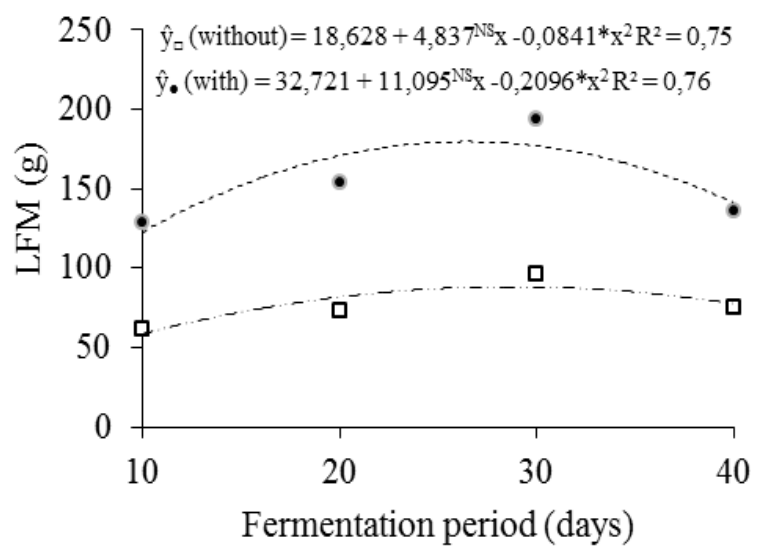

(E)

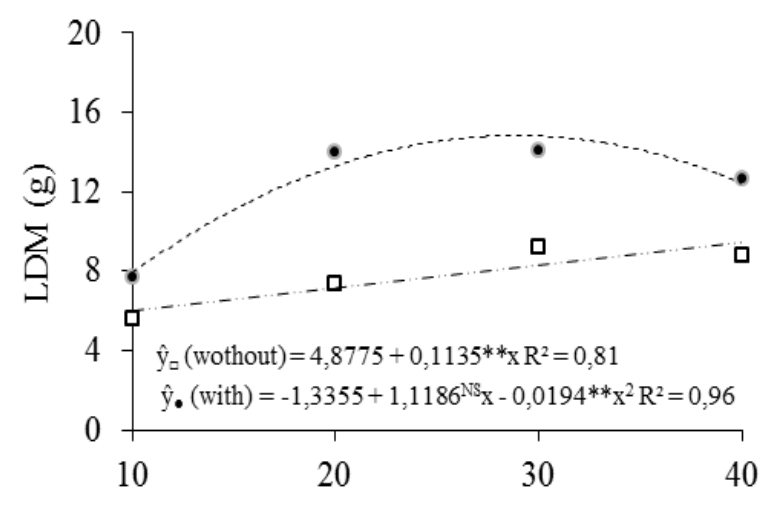

Fermentation period (days)

Ns,$* *$ e $*$ não significativo, significativo a 1 e $5 \%(\mathrm{p}<0,01$ e $\mathrm{p}<0,05)$ de probabilidade, respectivamente.

Figure 2. Tuberous root diameter-TRD (A), tuberous root fresh matter-TRFM (B), leaf fresh matter-LFM (C), tuberous root dry matter-TRDM (D) and leaf dry matter-LDM (E) of beet plants under fertilization with common and NPK-enriched biofertilizer in different fermentation periods.

The highest values of tuberous root diameter, tuberous root fresh matter, leaf fresh matter, tuberous root dry matter and leaf dry matter

NPK fertilization for the variables: tuberous root diameter, tuberous root fresh matter, leaf fresh matter, tuberous root dry matter and leaf dry matter of beet plants, cv. Katrina (Figure 2 A, B, C, D and E)..

(B)

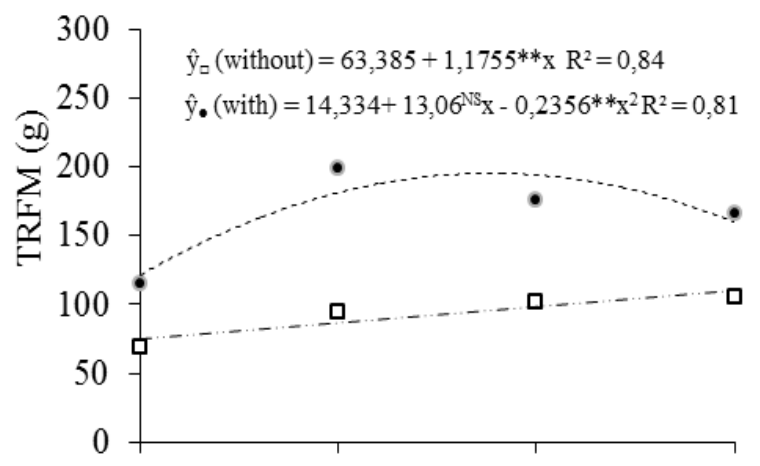

(D)

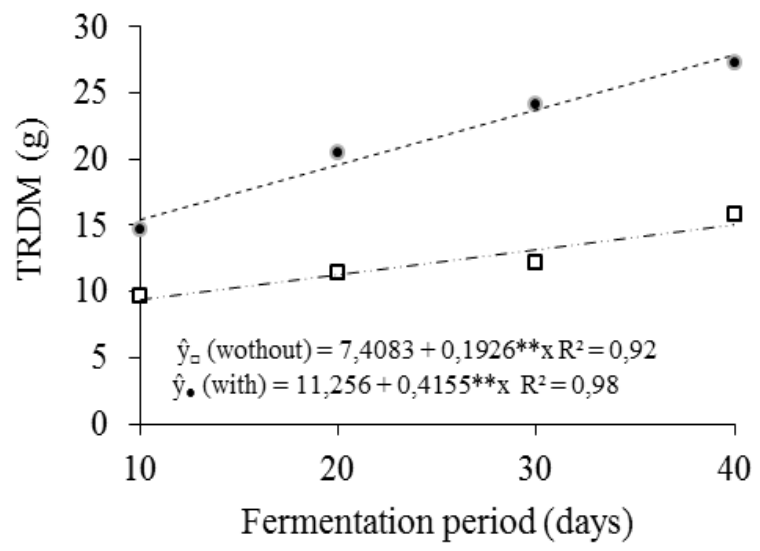

E) 
estimated fermentation period of 27 days; $195.17 \mathrm{~g}$ of TRFM for the estimated fermentation period of 28 days; $179.5 \mathrm{~g}$ of TRDM for the estimated fermentation period of 26 days; LFM of $27.9 \mathrm{~g}$ for the estimated fermentation period of 40 days, and $14.84 \mathrm{~g}$ of $\mathrm{LDM}$ for the estimated fermentation period of 29 days (Figure 2 A, B, C, D and E).

In the present study, the organo-mineral fertilization in the beet production led to tuberous root with $195.17 \mathrm{~g}$ per plant, a result much higher than those observed by Marques et al. (2010), who evaluated the effect of organic fertilization in the beet production and obtained $88.05 \mathrm{~g}$ per plant in the cultivar 'Early Wonder' using the bovine manure dose of $80 \mathrm{tha}^{-1}$, and by Castro et al. (2004), who observed yields of $77.0 \mathrm{~g}$ per plant in the cultivar 'Early Wonder tall top', $70.75 \mathrm{~g}$ per plant in the cultivar 'Rossete', $79.75 \mathrm{~g}$ per plant in the cultivar 'Avengere' and $73.25 \mathrm{~g}$ per plant in the cultivar 'Early Wonder Stay Green' with the application of the biofertilizer Agrobio

In the soil without mineral fertilization, there was an increasing linear behavior of the fresh matter accumulation of the tuberous root and dry matter of tuberous roots and leaves, as the biofertilizer fermentation period increased (Figure 2 $\mathrm{B}, \mathrm{D}$ and $\mathrm{E})$. For leaf fresh matter of the beet plants, there was a quadratic behavior with maximum accumulation of $82.2 \mathrm{~g}$ when plants were fertilized with biofertilizer fermented for 29 days (Figure 2C). The behavior observed in the present study may be related to the higher availability of nutrients in the biofertilizer under the longest fermentation period, since these treatments did not receive mineral fertilization with NPK. However, there was lower root diameter with the increase in the biofertilizer fermentation period. Thus, considering that there was increase in fresh and dry matter of the tuberous root in the absence of mineral fertilization, the plant must have prioritized its growth in length in detriment of diameter, in order to search for nutrients in the soil (Figure $2 \mathrm{~A}, \mathrm{~B}$ and D).

These results demonstrate that organomineral fertilization, relative to the combination of biofertilizer and NPK mineral fertilizer, is able to adequately meet the nutritional requirements of the beet crop, promoting improvements in photosynthetic activity, growth and production of this crop, in comparison to plants cultivated under fertilization with only biofertilizer. Similar results, with organo-mineral fertilization enhancing growth, gas exchanges and production, have also been observed in vegetables such as bell pepper (ARAÚJO et al., 2007), lettuce (ALVES et al., 2009), tomato (GOMES JÚNIOR et al., 2011), pumpkin (SANTOS et al., 2012), melon (VIANA et al., 2013; SANTOS et al., 2014) and gherkin (GOMES et al., 2015).

\section{CONCLUSIONS}

The organo-mineral fertilization with biofertilizer fermented for the period of 20 to 30 days, associated with mineral fertilization with $36 \mathrm{~g}$ $\mathrm{m}^{-2}$ of $\mathrm{P}_{2} \mathrm{O}_{5}, 18.0 \mathrm{~g} \mathrm{~m}^{-2}$ of $\mathrm{K}_{2} \mathrm{O}$ and $14 \mathrm{~g} \mathrm{~m}^{-2}$ of $\mathrm{N}$ at planting, promoted better performance in growth and gas exchanges and higher production of the beet crop.

In the soil without mineral fertilization, it is recommended to use the longest biofertilizer fermentation periods, from 30 to 40 days, for beet cultivation.

RESUMO: A cultura da beterraba tem grande importância econômica e alimentar no mundo, especialmente no que diz respeito à geração de energia. No Brasil, a cultura ainda é pouco estudada, faltando estudos em todos os estágios de produção da cultura, principalmente no manejo da adubação. Objetivou-se no presente trabalho, avaliar a adubação organomineral no crescimento, trocas gasosas e produção da beterraba cv. Katrina. O experimento foi conduzido em condições de campo, no município de Pombal, PB, no período de setembro a dezembro de 2015 . O delineamento experimental utilizado foi o de blocos ao acaso, com tratamentos arranjados em esquema fatorial 4 x 2 , relativos a quatro períodos de fermentação do biofertilizante (10, 20, 30 e 40 dias) aplicados em solos com e sem adubação mineral, com quatro repetições e 18 plantas úteis por parcela. As plantas foram conduzidas durante 70 dias após o transplantio, em canteiros de $15 \mathrm{~cm}$ de altura, com $1 \mathrm{~m}$ de largura. Durante esse período, avaliou-se o crescimento, trocas gasosas e os componentes de produção. A adubação com biofertilizante mineral fermentado no período entre 20 e 30 dias associado à adubação mineral com $36 \mathrm{~g} \mathrm{~m}^{-2}$ de $\mathrm{P}_{2} \mathrm{O}_{5}, 18,0 \mathrm{~g} \mathrm{~m}^{-2}$ de $\mathrm{K}_{2} \mathrm{O}$ e $14 \mathrm{~g} \mathrm{~m}^{-2}$ de $\mathrm{N}$ no plantio, proporcionou melhor desempenho no crescimento, trocas gasosas e produção da beterraba. No solo sem adubação mineral, recomenda-se a utilização dos maiores períodos de fermentação do biofertilizante, 30 a 40 dias, para o cultivo da beterraba.

PALAVRAS-CHAVES: Adubação mineral. Beta vulgaris L. Fermentação. Fertilizante líquido. 


\section{REFERENCES}

ALVES, G. S.; SANTOS, D.; SILVA, J. A.; NASCIMENTO, J. A. M.; CAVALCANTE, L. F.; DANTAS, T. A. G. Estado nutricional do pimentão cultivado em solo tratado com diferentes tipos de biofertilizantes. Acta Scientiarum. Agronomy, Maringá, v. 31, n. 4, p. 661-665, 2009. http://dx.doi.org/10.4025/actasciagron.v31i4.731

ALVES, S. M. C.; ABBOUD, A. C. S.; RIBEIRO, R. L. D.; ALMEIDA, D. L. Balanço do nitrogênio e fósforo em solo com cultivo orgânico de hortaliças após a incorporação de biomassa de guandu. Pesquisa Agropecuária Brasileira, Brasília, v. 39, n. 11, p. 1111-1117, 2004. http://dx.doi.org/10.1590/S0100204X2004001100009

ARAÚJO, E. M.; OLIVEIRA, A. P.; CAVAlCANTE, L. F.; PEREIRA, W. E.; BRITO, N. M.; NEVES, C. M. L; SILVA, E. E. Produção do pimentão adubado com esterco bovino e biofertilizante. Revista Brasileira de Engenharia Agrícola e Ambiental, Campina Grande, v. 11, n. 5, p. 466-470, 2007. http://dx.doi.org/10.1590/S1415-43662007000500003.

ARAÚJO, W. F.; SOUSA, K. T. S.; VIANA, T. V. A.; AZEVEDO, B. M.; BARROS, M. M.; MARCOLINO, E. Resposta da alface a adubação nitrogenada. Revista Agro@mbiente, Boa Vista, v. 5, n. 1, p. 12-17, 2011.

CASTRO, C. M.; ARAÚJO, A. P.; RIBEIRO, R. L. D.; ALMEIDA, D. L. Efeito de biofertilizante no cultivo orgânico de quatro cultivares de beterraba na baixada metropolitana do rio de janeiro. Revista Universidade Rural: Série Ciências da Vida, Rio de Janeiro, v. 24, n. 2, p. 81-87, 2004.

CATUCHI, T. A.; GUIDORIZZI, F. V. C.; GUIDORIZI, K. A.; BARBOSA, A. M.; SOUZA, G. M. Physiological responses of soybean cultivars to potassium fertilization under different water regimes. Pesquisa Agropecuária Brasileira, Brasília, v. 47, n. 4, p. 519-527, 2012. http://dx.doi.org/10.1590/S0100204X2012000400007

CORRÊA, C. V.; CARDOSO, A. I. I.; SOUZA, L. G.; ANTUNES, W. L. P.; MAGOLBO, L. A. Produção de beterraba em função do espaçamento. Horticultura Brasileira, Brasília, v. 32, n. 1, p. 111-114, 2014. http://dx.doi.org/10.1590/hb.v32i01.27

FERREIRA, D. F. Sisvar: a computer statistical analysis system. Ciência e Agrotecnologia, Lavras, v. 35, n. 6 , p. 1039-1042, 2011. http://dx.doi.org/10.1590/S1413-70542011000600001

GOMES JÚNIOR, J.; SILVA, A. J. N.; SILVA, L. L. M.; SOUZA, F. T.; SILVA, J. R. Crescimento e produtividade de tomateiros do grupo cereja em função da aplicação de biofertilizante líquido e fungo micorrízico arbuscular. Revista Brasileira de Ciências Agrárias, Recife, v. 6, n. 4, p. 627-633, 2011. http://dx.doi.org/10.5039/agraria.v6i4a1362

GOMES, L. P.; OLIVEIRA, F. A.; BEZERRA; F. M. S.; LIMA, L. A.; COSTA, L. P.; GUEDES, R. A. A. Produtividade de cultivares de maxixeiro em função de doses de biofertilizante. Revista Agro@mbiente, Boa Vista, v. 9, n. 3, p. 275-283, 2015.

MARQUES, L. F.; MEDEIROS, D. C.; COUTINHO, O. L.; MARQUES, L. F.; MEDEIROS, C. B.; VALE, L. S. Produção e qualidade da beterraba em função da adubação com esterco bovino. Revista Brasileira de Agroecologia, Porto Alegre, v. 5, n. 1, p. 24-31, 2010.

RAIJ, B. V.; CANTARELLA, H.; QUAGGIO, J. A.; FURLANI, A. M. C. Recomendações de adubação e calagem para o Estado de São Paulo. 2.ed. Campinas: Instituto Agronômico/ Fundação IAC. 1997. 285p. 
SÁ, F. V. S.; BRITO, M. E. B.; SILVA, L. A.; CAVALCANTE, L. F.; MOREIRA, R. C. L.; FIGUEIREDO, L. C.; PAIVA, E. P. Growth and gas exchanges of papaya tree seedlings grown on alternative substrates. Científica: Revista de Agronomia, Botucatu, v. 44, n. 2, p. 245-254, 2016. http://dx.doi.org/10.15361/1984$5529.2016 \mathrm{v} 44 \mathrm{n} 2 \mathrm{p} 245-254$

SANTOS, A. P. G.; VIANA, T. V. A.; SOUSA, G. G.; GOMES-DO-Ó, L. M.; AZEVEDO, B. M.; SANTOS, A. M. Produtividade e qualidade de frutos do meloeiro em função de tipos e doses de biofertilizantes. Horticultura Brasileira, Brasília, v. 32, n. 4, p. 409-416, 2014. http://dx.doi.org/10.1590/S0102053620140000400007.

SANTOS, M. R.; SEDIYAMA, M. A. N.; MOREIRA, M. A.; MEGGUER, C. A.; VIDIGAL, S. M. Rendimento, qualidade e absorção de nutrientes pelos frutos de abóbora em função de doses de biofertilizante. Horticultura Brasileira, Brasília, v. 30, n. 1, p. 160-167, 2012. http://dx.doi.org/10.1590/S010205362012000100027

SEDIYAMA, M. A. N.; SANTOS, M. R.; VIDIGAL, S. M.; PINTO, C. L. O.; JACOB, L. L. Nutrição e produtividade de plantas de pimentão colorido, adubadas com biofertilizante de suíno. Revista Brasileira de Engenharia Agrícola e Ambiental, Campina Grande, v. 18, n. 6, p. 588-594, 2014. http://dx.doi.org/10.1590/S1415-43662014000600004

SHRESTHA, N.; GEERTS, S.; RAES, D.; HOREMANS, S.; SOENTJENS, S.; MAUPAS, F.; CLOUET, P. Yield response of sugar beets to water stress under Western European conditions. Agricultural Water Management, New York, v. 97, n. 2, p. 346-350, 2010. http://dx.doi.org/10.1016/j.agwat.2009.10.005

SILVA, F. A. M.; BÔAS, R. L. V.; SILVA, R. B. Resposta da alface à adubação nitrogenada com diferentes compostos orgânicos em dois ciclos sucessivos. Acta Scientiarum Agronomy, Maringá, v. 32, n. 1, p. 131137, 2010. http://dx.doi.org/10.4025/actasciagron.v32i1.134010.4025/actasciagron.v32i1.1340.

SILVA, J. A.; OLIVEIRA, A. P.; ALVES, G. S.; CAVALCANTE, L. F.; OLIVEIRA, A. N. P.; ARAÚJO, M. A. M. Rendimento do inhame adubado com esterco bovino e biofertilizante no solo e na folha. Revista Brasileira de Engenharia Agrícola e Ambiental, Campina Grande, v. 16, n. 3, p. 253-257, 2012. http://dx.doi.org/10.1590/S1415-43662012000300003.

TAIZ, L.; ZEIGER, E. Fisiologia vegetal. 5.ed. Porto Alegre: Artmed, 2013. 918p.

VIANA, T. V. A.; SANTOS, A. P. G.; SOUSA, G. G.; PINHEIRO NETO, L. G.; AZEVEDO, B. M.; AQUINO, B. F. Trocas gasosas e teores foliares de NPK em meloeiro adubado com biofertilizantes. Revista Brasileira de Ciências Agrárias, Recife, v. 8, n. 4, p. 595-601, 2013. http://dx.doi.org/10.5039/agraria.v8i4a3260. 